Volume 250

\section{Britain takes up the SGHWR}

AFTER four years of debate, during which it often seemed that no decision would ever be made, the government has finally jumped off the fence, bowling over Sir Arnold Weinstock and the Central Electricity Generating Board (CEGB) in the process. For, like it or not, the CEGB is going to have to order a small number of steam generating heavy water reactors (SGHWRs) in the next few years rather than a considerably larger number of the American pressurised water reactors (PWRs) which it favours.

The remarkable thing about all this is that the decision could equally well have been made in 1972 when Mr John Davies, then Secretary of State for Trade and Industry, announced a programme of component development for the SGHWR. Other options for the short term could still have been kept open and indeed that is exactly what $\mathrm{Mr}$ Eric Varley, Secretary of State for Energy, has done nearly two years afterwards in saying that the Nuclear Installations Inspectorate should complete its examination of the safety of the American reactors.

Even if $\mathrm{Mr}$ Davies had also opted for a relatively modest scheme, Mr Varley might now be in a position to enlarge a programme to which the nuclear power industry and the CEGB would have had two years to adjust. As it is, Sir Arnold, who is head of GEC (a 50\% stakeholder in the National Nuclear Corporation), is sulking and threatening to reduce considerably, or even eliminate, his company's share in the corporation. That would be embarrassing, as GEC is supposed to manage the building of the next generation of nuclear reactors in Britain and it will no doubt cause wry smiles among members of the Select Committee on Science and Technology which thinks that a shareholding of more than $30 \%$ by any commercial interest should not have been allowed in the first place. In fact it is difficult to see how the corporation could continue if Sir Arnold were to depart completely.

Ultimately, however, it is the CEGB which has to generate the electricity and its views deserve the most sympathetic consideration. It is that body, one has to bear in mind, which still has all five advanced gas cooled reactor stations waiting to be completed almost ten years after the first one was ordered. Basically the CEGB wants to order nuclear power stations in such numbers over the next decade or so that its reliance on fossil fuel is decreased, and it wants those nuclear power stations to work properly. Not surprisingly, therefore, it criticises the government's decision on the grounds that the SGHWR is untried in a commercial situation and that because of this the government is only risking a programme of some $4,000 \mathrm{MW}$ to be ordered over the next four years and commissioned in the 1980s. Even the quite modest rate of growth of electricity demand now envisaged by the Department of Energy requires $35,000 \mathrm{MW}$ of new capacity by 1990 , the lion's share of which will evidently be based on fossil fuels unless the SGHWR turns out to be such a success that more can be rapidly ordered after the first has become operational, perhaps in 1981.

The CEGB points out, and the government apparently agrees, that more development work will have to be done before the SGHWR can be built on even the scale that $\mathrm{Mr}$ Varley envisages (small units of $660 \mathrm{MW}$ ). The argument goes that the test reactor at Winfrith is only 1,00 MW and is based on technology that is already 10 years old. Parts will have to be redesigned, says the CEGB, and different materials will have to be used. But is all this really necessary? Does a new piece of functional equipment necessarily have to incorporate the most upto-date technology wherever possible? Excessive zeal in this direction would seem to be ill advised, especially if an attempt to wring that extra bit of efficiency or cost out of the system were to cause more expense in the long run than could ever be saved. After all the suggestion that more Magnox stations should be built is only a nonstarter because of the high capital cost compared with more modern reactor designs.

What the CEGB seem to overlook is that the Canadian CANDU reactor, which is similar in many ways to the SGHWR, has been working successfully for several years and that technological cooperation between Britain and Canada is thought by both countries to be a mutually advantageous prospect. And there seems no reason why Britain should not now take advantage of the export opportunities which may still exist for the SGHWR.

\section{0 years ago}

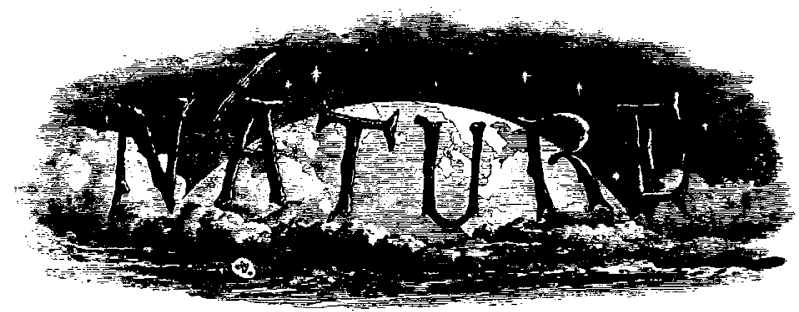

WE rejoice to see from the tone of the replies to questions in the House of Commons on Monday by Mr. Disraeli and Lord Henry Lennox, that Government is conscious of how poorly housed some of our scientific collections are, and seems really disposed to take steps to remedy the evil. Mr. Disraeli said, in reply to a question concerning the Patent Museum, that it is not the only public institution which is suffering from want of space and of suitable accommodation. "That is now a crying grievance with respect to all our public buildings, collections, and offices. In regard to the Patent Museum, however, $I$ am aware from a communication which $I$ have received from my noble friend the First Commissioner of Works, that the inatter is at present engaging attention." Lord Henry Lennox confirmed this by subsequently stating that he intended to propose to Her Majesty's Government a scheme which, if it were agreed to, would enable him to offer the Patent Museum suitable accommodation in the southern block of the International Exhibition buildings. 